Asian J. Med. Biol. Res. 2020, 6 (1), 81-92; doi: 10.3329/ajmbr.v6i1.46482

\author{
Asian Journal of \\ Medical and Biological Research \\ ISSN 2411-4472 (Print) 2412-5571 (Online) \\ www.ebupress.com/journal/ajmbr
}

\title{
Article \\ Impacts of climate change on livelihood of the fishers' at the Meghna, Laukhati
and Galachipa river in Bangladesh
}

Md. Jiaur Rahaman, Md. Saddam Hossain, Mohammad Matiur Rahman and Zakir Hossain*

Department of Fisheries Biology and Genetics, Bangladesh Agricultural University, Mymensingh-2202, Bangladesh

*Corresponding author: Professor Dr. Zakir Hossain, Department of Fisheries Biology and Genetics, Faculty of Fisheries, Bangladesh Agricultural University, Mymensingh-2202, Bangladesh. Phone: +8801724-939696; Fax: +88091-61510; E-mail: zakir.fbg@ bau.edu.bd

Received: 25 February 2020/Accepted: 28 March 2020/ Published: 31 March 2020

\begin{abstract}
Climate change is a global threat to the world especially for Bangladesh, due to its geographical location. The present study was carried out to the impacts of climate change on livelihood of the fishers at the Meghna, Laukhati and Galachipa river in Bangladesh. The study was assessing the effects of climate change on fishers' community in the Meghna, Laukhati and Galachipa rivers near Chandpur and Patuakhali districts. The data on fishers' livelihood were collected by using a well-developed questionnaire from the selected areas. The average temperature was recorded as $30.5 \pm 0.90^{\circ} \mathrm{C}, 27.1 \pm 1.05^{\circ} \mathrm{C}$ and $27.4 \pm 0.60^{\circ} \mathrm{C}$ and the dissolved oxygen was as $6.37 \pm 1.11 \mathrm{mg} / \mathrm{L}, 5.63 \pm 0.33 \mathrm{mg} / \mathrm{L}$ and $6.33 \pm 0.51 \mathrm{mg} / \mathrm{L}$ in the Meghna, Laukhati and Galachipa rivers, respectively. The $\mathrm{pH}$ was as $8.3 \pm 0.59,8.03 \pm 0.50$ and $7.8 \pm 0.50$ and the salinity was as $0.10 \pm 0.10,0.23 \pm 0.13$ and $1.2 \pm 0.15 \mathrm{ppt}$ in the Meghna, Galachipa and Laukhati rivers, respectively. In the present study, it was found that most of the fishers were belonged to the age groups of 41 to 60 years (45\%), represented by $75 \%$ muslim and joint family type $(61 \%)$ was the predominant among the fishers. The highest annual income of fishers was found 20,080 and 24,000 BDT per year at Chandpur and Patuakhali districts, respectively. There has not been conducted much empirical research about the impacts of climate change in the present research areas. Therefore, Government and NGOs should take proper steps by taking various need based projects and providing some sorts of management policy to rescue the vulnerable communities from climate change impacts.
\end{abstract}

Keywords: economic impact; habitat; livelihood pattern; literacy rate; rainfall

\section{Introduction}

Climate change is the most discussing topic in the recent years as it is impacting every spheres of earth including physical, natural, socio-economic domain, foods and livelihood of people. The environment and natural resources of the most Asian country are adversely affecting by the climate change. Bangladesh is most vulnerable country depending on the vulnerability of national economics to the impacts of climate change on fisheries resources (Allison et al., 2009). The fishers' communities are facing the challenges due to hydro meteorological changes caused by climate change (Moni and Hossain, 2010). Climate change may directly affect fish reproduction, growth and migration patterns by temperature, rainfall and hydrology (Ficke et al., 2007). Climate change is evolving to threat on natural ecosystems and human livelihoods in Bangladesh as it has flat deltaic topography with very low elevation and extreme climate as it has high population density and majority of population being dependent on crop agriculture which has highly influenced by climate change. Fisheries resources are most prone to climate change on which millions of fishers' livelihoods depend on fisheries resources of the country. The vulnerability to climate change and climate related disasters is influenced by the complex array of social, economic, political, and environmental factors (O'Briena et al., 2004). Water resources sector deals vulnerability of the different combination of climate change and sea level rise options i.e. 
changes in river water level in monsoon which would reflect the change in depth of inundation, salinity intrusion due to sea level rise and low water flow from upstream during the winter. Salinity intrusion due to reduction of freshwater flow affected groundwater and increased soil salinity are major concerns on Bangladesh. Bangladesh is the most vulnerable to the impacts of salinity intrusion, as newly saline intruded areas are increasing day by day (Rahman, 2009). This vulnerability is adding more pressure to the existing problems water scarcity for the increased population in Bangladesh is severe during the dry season (ADB, 2005).

There are numerous rivers in Bangladesh and it plays as a great source of various fishes. The Meghna river is one of them. It discharges the joint flow of the Ganges-Padma, the Brahmaputra-Jamuna and the Meghna (joint flow of the Surma- Kushiyara) itself. Down of the Meghna river a huge widespread estuary formed which is rich in nutrients and finally ends in the Bay of Bengal (Kamal and Khan, 2009). The Meghna river estuary is the biggest estuary and occupying almost whole central coast of Bangladesh. The Meghna estuary contributes a large portion in the national economy as well as the Galachipa river and the Laukhati river of Patuakhali district and it also supports a great portion of fisheries resources for Bangladesh. The estuary is exclusively important part of aquatic habitat of Bangladesh, which has a great contribution of highly productive ecosystem (Honggang et al., 2012). It plays a significant role in nutrient recycling and serves as a favourable breeding and nursing grounds for many commercially important shell fishes and finfishes (Haedrich, 1983). Moreover, many marine, brackish and freshwater animals largely depend on estuarine environment in their life history or entire life cycle. Fish and fisheries products play a significant role in Bangladesh as a principal source of animal protein in daily diet of human. About $2 \%$ of the population in Bangladesh is engaged in aquaculture, but most of the fishers are involved in fishing round year (Ahmed, 2008). Fishers are affected by changes of climate that are ultimately driven by rising global temperatures. For example, coastal fishers in Bangladesh face increased frequency and severity of cyclones with severe penetration of saline water into coastal land due to thermal expansion of the warming Bay of Bengal, the people of the Chandpur and Patuakhali districts converge around the Meghna river, as regional warming drives decreased rainfall and increased evapotranspiration (Coe and Folley, 2001), set within a context of overexploitation of the fisheries resources (Mullon et al., 2005). Although the Meghna, Laukhati and Galachipa rivers have high importance of fisheries resources for fishers but there is no comprehensive report on effects of climate change on livelihood of the fishers in these rivers. The impacts of climate change cover comprehensive aspects of rural livelihoods, there is a critical challenge to understand the broad significance to fisheries resource and livelihood status with climate change and to concentrate on people's needs to build their resilience. Therefore, the present study was undertaken to evaluate the impacts of climate change on livelihood of the fishers living around the rivers Meghna, Laukhati and Galachipa.

\section{Materials and Methods}

\subsection{Description of the study area}

The four major fish landing stations of Chandpur and Patuakhali district were selected for the study area. The GPS reading of those sampling stations were taken by using GPS meter. Boro Station Fish Landing Center $23013.812^{\circ} \mathrm{N}-90038.552^{\circ} \mathrm{E}$ and Biponibug bazar $24.7255114^{\circ} \mathrm{N}-90.4401682^{\circ} \mathrm{E}$ at Chandpur; Dashmina $22.2833^{\circ} \mathrm{N}-90.5903^{\circ} \mathrm{E}$ and Galachipa $22.1639^{\circ} \mathrm{N}-90.4306^{\circ} \mathrm{E}$ at Patuakhali district (Figure 1).

\subsection{Observation of water quality parameters}

Water quality parameters were recorded once per month from the different place of Meghna river at Chandpur and the Galachipa and Laukhati river at Patuakhali. Dissolved oxygen (DO), pH, salinity and water temperature were determined using a DO meter (Model: DO-5509, China), a portable digital pH meter (HI 98107, Romania), refractometer (ATAGO, S/Mill, salinity. 0-100 \%, Japan) and Celsius thermometer, respectively.

\subsection{Data collection}

The fishers' livelihood data was collected through semi-structured questionnaire interview and Focused Group Discussion (FGD) method. Fishers' interview and FGD had been done in fish landing centers, fish market, boat owners of commercial fishing vessels, retailers, fish traders, local people, fishers, riverside settlers and fishers' village of those selected sampling areas for the collection of information on fisheries resources and livelihood data. Households were selected as the sampling unit considering the factors that one member of each household was permanent resident of the study area and was involved with fish catch or fish farming. The minimum age of each respondent was considered 40 years so that they could provide more accurate information.

The Secondary data was collected from various relevant scientific articles, reports, maps, journals, website, library, Bangladesh Fisheries Research Institute, Department of Fisheries and Department of Forestry. 


\subsection{Sustainable livelihood approach (SLA)}

SLA is an attempt to recognize climate changes impact and variation fishers' community at Kishoreganj haor region. There are three major components such as livelihood asset (natural, financial, social, human and physical capital), vulnerability context (vulnerability analysis) and structure and process (institutional analysis) in the framework of SLA. The principle of the SLA into the regulation of community based climate change impact and adaptation in a specific way were maintained for the current study.

\subsection{Data processing and analysis}

The collected information were coded, summarized and processed for analysis. Tabular technique was applied for the analysis of data by using simple statistical tools like averages and percentages. Collected data has been analyzed by Microsoft Excel.

\section{Results and Discussion}

\subsection{Observation of rainfall in the study area}

Rainfall is an important factor which influences the environment. The frequency of heavy rainfall and the perception level over the present study area is changing day by day. It can lead to numerous hazards such as flooding, landslides, loss of crops and livestock, disrupt transport and communications, and cause damage to buildings and infrastructure. The fluctuation of heavy rainfall in the present study areas with few decades are showed in Figure 2. Talukder et al. (1988) found that the highest rainfall in July $(387.8 \mathrm{~mm})$ and lowest in January $(3.6 \mathrm{~mm})$ and the mean annual rainfall was $2485.95 \mathrm{~mm}$ various location in Bangladesh for a period of 18 years (1965-1980). Ali et al. (1994) found that the rainfall of the wettest year 1991 was $136.15 \%$ of the average of $2485.5 \mathrm{~mm}$ while the driest year of 1992 was $63.61 \%$ of the 19 years (1975 to 1993).

\subsection{Observation of water quality parameters in the study area}

The average temperature was recorded $30.5 \pm 0.90^{\circ} \mathrm{C}, 27.1 \pm 1.05^{\circ} \mathrm{C}$ and $27.4 \pm 0.60^{\circ} \mathrm{C}$ and the dissolved oxygen was $6.37 \pm 1.11 \mathrm{mg} / \mathrm{L}, 5.63 \pm 0.33 \mathrm{mg} / \mathrm{L}$ and $6.33 \pm 0.51 \mathrm{mg} / \mathrm{L}$ in the Meghna, Laukhati and Galachipa rivers, respectively. The $\mathrm{pH}$ was $8.3 \pm 0.59,8.03 \pm 0.50$ and $7.8 \pm 0.50$ and the salinity was $0.10 \pm 0.10,0.23 \pm$ 0.13 and $1.2 \pm 0.15 \mathrm{ppt}$ in the Meghna, Galachipa and Laukhati rivers, respectively. Temperature is an essential climatic parameter. It affects evaporation from open water. At present the most concerning issue is rising temperature. This rising temperature is as threatened as dangerous to the living organisms on the earth. Rahaman et al. (2019) found similar result in the Meghna, Galachipa and Laukhati rivers. Hossain et al. (2018) also found similar result in the Meghna river.

\subsection{Religion and age structure}

The religion of the $75 \%$ and $25 \%$ of the fishers were muslims and hindus, respectively. The age groups as young (20-30 years), middle aged (31-40 years) and old (41-60 years) were considered as qualified respondents. It appeared that age group of 41-60 years was the highest (45\%) and 20-30 years was the lowest (23\%) considering all fishers (Figure 3). Ali et al, (2008) found the similar result; most of the fishers were Muslim (75\%) and $60 \%$ fishers belong to age group of 31 to 40 years at Lohalia river in Patuakhali. Hassan and Mahmud (2002) reported that the majority of fishers were muslim (93.94\%) in Kuakata and 32\% hindu fishers were found at Sundarban in the coastal fishing community. Mahmud et al. (2015) found $54 \%$ and $46 \%$ fishers were muslims and hindus, respectively; and also found $18 \%$ peoples were at the age group between 10 to 20 , $50 \%$ peoples belong to age group between 21 to $40,22 \%$ peoples were between 41 to 60 and $10 \%$ peoples were more than 60 age group at the paira river, Patuakhali.

\subsection{Family type}

In the present study, families were classified into two types such as nuclear family and joint family. About $61 \%$ of fishers lived in joint families and 39\% in nuclear families at Chandpur Sadar Upazila and Dashpara near Meghna River. About $84 \%$ of fishers lived in joint families and 16\% in nuclear families at Patuakhali Sadar and Dashmina Upazila near Laukhati and Galachipa river (Figure 4). Mahmud et al. (2015) found similar result, $85 \%$ fishers' family were jointed family at the Paira river, Patuakhali.

\subsection{Educational level}

Fishers were categorized into five categories on the basis of the level of education. In this study area, primary, secondary education levels were highest at Chandpur and Patuakhali (Figure 5). Literacy rate was not satisfactory in the fishers communities of the study area. Mahmud et al. (2015) found that 46\%, $14 \%$ and $2 \%$ 
peoples had passed primary, secondary and higher secondary, respectively at Paira river, Patuakhali. Zaman $e t$ al. (2006) reported that $23.3 \%$ fishers were illiterate whereas $14.4 \%, 8.9 \%$ and $6.7 \%$ were educated up to primary, secondary and higher secondary or above level, respectively at Mohanpur Upazila in Rajshahi District.

\subsection{Natural capital}

Natural capital of fishers included the land, open water, fish availability, soil type, and wider environmental goods that are critical for fishers. Climate change and rapid population growth had some extent to accelerate natural capital depletion that had affected their income. The existence of floodplains, lack of natural food (both phytoplankton and zooplankton) in the vicinity of the present study area offer tremendous scope for harnessing natural resources for sustainable livelihood management of the fishing community. In addition, Ahmed and Hossain (1999) found that about 34\% fishers depending on crop cultivation as subsidiary occupation in Mymensingh region.

\subsection{Sources of credit}

In the present study, it was found that $41 \%$ fishers received loan from different NGOs, $32 \%$ of the fishers used their own money for fishing, $17 \%$ borrow from relatives and $10 \%$ of the fishers borrow from neighbors at Chandpur and 38\% received loan from different NGOs, 29\% self-dependent, $21 \%$ from relatives, $12 \%$ from neighbors at Patuakhali region (Figure 6). Mahmud et al. (2015) found that 30\% became self-sufficient who did not need financial help but $24 \%$ borrow money from their neighbours, $22 \%$ from relatives, $16 \%$ from NGO's and 8\% from co-operatives for their fishing business of Paira river, Patuakhali. Quddus et al. (2000) found that only 34\% fishers got bank loan for fishing while Majority (53\%) of fishers expend from their own sources. Small fishers were found in disadvantageous situation due to poor financial resources for fishing and they did not have financial support from institutional credit.

\subsection{Annual income}

The Annual income of fishers was varied from 20,000 to 100000 BDT. The selected fishers were grouped into four categories based on the level of their annual income. The highest percentage (44\%) of fishers earned 20,080 to 24,000 BDT per year at Chandpur and 46\% at Patuakhali (Table 1). Paul et al. (2013) found that about 63\% fishers had a moderate annual income (30000-60000 BDT) at the Turag River, Bangladesh. Ali et al. (2008) reported that the average annual incomes of majority of fishers in Hamirkutsha and Kamarbari of Bagmara upazilla under Rajshahi district were above 75,000 BDT per year. Baki et al. (2015) reported the annual income of fishers varied from 60,000 to 85,000 BDT at the fishing community in adjacent areas of Turag-Burigonga river, Dhaka, Bangladesh.

\subsection{Housing condition}

The nature of housing of people indicates the social status of a nation. Fishers house in Chandpur district was not developed. So, $74 \%$ of the house of fishers was tin-shed, $19 \%$ semi-cemented building and $7 \%$ cemented building. In addition, $76 \%$ was made of tin-shed, $20 \%$ half cemented building and $4 \%$ was cemented building at Patuakhali (Figure 7). Paul et al. (2013) reported that 72\% fishers had semi tin-shed and $28 \%$ had tin-shed house at the Turag river, Bangladesh. Ali et al. (2008) reported that about 54\% of the fishers in Bagmara upazilla under Rajshahi district have tin-shed house while $26 \%$ and $14 \%$ of the fishers have half-building and building house respectively.

\subsection{Health facilities}

Health facilities of the fishers were very poor as $57 \%$ of the fishers were dependent on Upazila health complex, $27 \%$ on village doctors and $16 \%$ on registered physicians, respectively at Chandpur while $46 \%$ on upazila health complex, $45 \%$ on village doctor and 9\% on registered physicians at Patuakhali (Figure 8). Pravakar et al. (2013) reported that health facilities of the fishers at the Shahrasti Upazila in Chandpur were poor and it was found that $70 \%$ of the fishers were dependent on village doctors, while $20 \%$ and $10 \%$ got health service from Upazila health complex and registered physicians, respectively.

\subsection{Drinking water sources}

The clean and safe drinking water is the right for the people of a nation. The study showed that $87 \%$ of the fishers used tube-well water for drinking purposes; about 13\% depend on river water at Chandpur Sadar Upazila while 91\% depends on tube-well and 9\% on river at Dashmina upazila of Patuakhali. Kabir et al. (2012) found 
that $100 \%$ fishers household used tube-well water for drinking purposes, among them $40 \%$ had their own tubewell, 50\% used shared tube-well and remaining 10\% used neighbours tube-well in the old Brahmaputra river area of Mymensingh, Bangladesh.

\subsection{Sanitary facilities}

Two types of toilets mainly used such as semi-cemented toilet made of tin or wood with inadequate drainage disposal and cemented toilet made of brick with good drainage disposal. It was found that $59 \%, 13 \%, 21 \%$ and $7 \%$ of fishers used tin-shed, semi-cemented, cemented and open toilet respectively at Chandpur where as 52\%, $26 \%, 16 \%$ and $6 \%$ at Patuakhali region (Figure 9). Kabir et al. (2012) noted that about $60 \%$ of the fishers used unhygienic while $10 \%$ used semi-hygienic and $30 \%$ of the fishers had no sanitary toilet facilities and also found $40 \%$ fishers used their own tube-well, 50\% used shared tube-well and remaining 19\% used neighbours tube-well for drinking water. Ali et al. (2009) found that $62.5 \%$ of the fishers had semi-cemented, $25 \%$ had tin-shed and $12.5 \%$ had cemented toilet at Tarakanda Upazila of Mymensingh district.

\subsection{Social status of fishers}

Ninety percent of the fishers had ordinary social status, $3 \%$ were local leaders and $7 \%$ were respectable persons in the society. Ali et al. (2009) found the similar result belonged to livelihood status of the fishers in some selected areas of Shahrasti Upazila of Chandpur district.

\subsection{Fishers' comments about the present condition of the rivers}

Most of the fishers go for fishing in the river 10-12 km away from their residences. For this reason, they usually used to go as a team of partnership. Generally, they went twice a day for fishing. They have been doing this work since 20-30 years. Therefore, they have mammoth experience about the wave pattern, flow of water, high tide, low tide, abundance and the extinction of the fish species in the river. Fishers' agreement on choice of fish price, irregular change, fishing zone alter, fish found less amount in river and decreases of water were 9\%, 87\%, 93\%, $81 \%$ and $100 \%$, respectively. Fishers said that the price of fish is not good enough to do well their socioeconomic condition. They said about the decreases of water level and amount of fish in river. Das et al. (2015) found the similar result about the present condition of the rivers in the south west region of Bangladesh.

\subsection{Climatic effect on fish and their habitats}

In the present study, fishers estimated about the effects of climate change on fisheries resources and its deleterious effects. Temperature, irregular rainfall, intrusion of salinity and other natural calamity are influencing extremely on the crucial fisheries resources. Fishers' agreement on increased temperature, increased cost of fishing materials, reduced fish production, intensify soil erosion, block of fish migration route, damaged biodiversity, changing water flow level, extinct fish species, reduced rainfall and storm frequency were $96.25 \%, 91.25 \%, 76.25 \%, 68.3 \%, 66.25 \%, 53.75 \%, 51.25 \%, 48.75 \%, 47.5 \%$ and $40 \%$, respectively; On the contrary, disagreed fishers were $1 \%, 3.1 \%, 12 \%, 12.9 \%, 17.3 \%, 43.75 \%, 23.8 \%, 13.7 \%, 15.7 \%$ and $35.7 \%$, respectively and no comments ranking were $2.75 \%, 5.65 \%, 11.25 \%, 18.8 \%, 16.45 \%, 2.5 \%, 24.75 \%, 37.55$, $10.5 \%$ and $37 \%$, respectively (Figure 10). Agrawala et al. (2003) found the similar effect of climate change on fish populations and their habitats at Sundarban in Bangladesh.

\subsection{Impact of climate change on livelihood pattern}

Climate change creates numerous hazards event and these badly affect on fishers' livelihood patterns. The augmentation in frequency and intensity of natural disasters, i.e. floods and cyclones, has made it arduous for the fishers to secure their livelihood. In the present study area, rainfall is increasing both in terms of amount and timing. The flood and cyclone affect fisheries severely while effects on other shocks such as drought, intrusion of salinity, heat wave, cold wave, fogginess is low to moderate. This leads to loss of livelihoods of the poor fishers in the present study area. Moreover, frequent warnings of cyclone lead the fishers to stay at home for longer periods and their income decreased which increased their poverty level. Here, Leopold matrix is used to identify the impact of hazard events on livelihood patterns. Impact factors have been evaluated separately for each hazard event and relevant livelihood pattern, and scored on a scale from 0 to 4 for impact magnitude, according to the following scale: 0 . no observable effect; 1 . low effect; 2 . tolerable effect; 3 . high effect; 4 . very high effect (devastation). From the Leopold matrix it can be said that the impact of hazardous events on livelihood is tolerable (Table 2 and Table 3). Sufian et al. (2017) investigated similar problems and constraints associated with fishing and livelihood in Dekar haor of Sunamganj in Bangladesh and also noted that housing 
Asian J. Med. Biol. Res. 2020, 6 (1)

and sanitation conditions of the fishers were not well developed and the highest percentage fishers were illiterate due to economic crises and lack of awareness about education.

Table 1. Annual incomes of fishers in the study area.

\begin{tabular}{lll}
\hline Annual Incomes (USD) & Chandpur & Patuakhali \\
\hline Up to 250 & 25 & 23 \\
$251-300$ & 44 & 46 \\
$301-375$ & 21 & 16 \\
$>625$ & 10 & 15 \\
\hline
\end{tabular}

(1 USD @ 80 BDT)

Table 2. Ranking of hazardous events at Dashmina and Patuakhali sadar upazila.

\begin{tabular}{|c|c|c|c|c|c|c|c|}
\hline \multirow[b]{2}{*}{ Hazard } & \multicolumn{5}{|c|}{ Frequency and intensity priority $(\%)$} & \multirow{2}{*}{$\begin{array}{l}\text { Total } \\
\text { frequency }\end{array}$} & \multirow[b]{2}{*}{ Ranking } \\
\hline & $\begin{array}{l}\text { Very } \\
\text { high (4) }\end{array}$ & High (3) & Medium (2) & Low (1) & No (0) & & \\
\hline Flood & 50 & 21 & 22 & 7 & 0 & 100 & 1 \\
\hline Cyclone & 49 & 25 & 21 & 5 & 0 & 100 & 2 \\
\hline Storm surge & 46 & 23 & 27 & 4 & 0 & 100 & 3 \\
\hline River Erosion & 26 & 31 & 26 & 6 & 11 & 100 & 4 \\
\hline Temperature & 21 & 45 & 21 & 9 & 4 & 100 & 5 \\
\hline Densely fog & 11 & 24 & 41 & 19 & 5 & 100 & 6 \\
\hline Drought & 2 & 6 & 5 & 40 & 47 & 100 & 7 \\
\hline High Tide & 1 & 11 & 23 & 22 & 43 & 100 & 8 \\
\hline
\end{tabular}

Table 3. Ranking of hazardous events at Sadar Upazila, Chandpur.

\begin{tabular}{|c|c|c|c|c|c|c|c|}
\hline \multirow[b]{2}{*}{ Hazard } & \multicolumn{5}{|c|}{ Frequency and intensity priority (\%) } & \multirow{2}{*}{$\begin{array}{l}\text { Total } \\
\text { frequency }\end{array}$} & \multirow[b]{2}{*}{ Ranking } \\
\hline & $\begin{array}{l}\text { Very high } \\
\text { (4) }\end{array}$ & High (3) & Medium (2) & Low (1) & No $(0)$ & & \\
\hline Flood & 57 & 21 & 15 & 7 & 0 & 100 & 1 \\
\hline Cyclone & 54 & 22 & 19 & 5 & 0 & 100 & 2 \\
\hline Storm surge & 51 & 27 & 18 & 4 & 0 & 100 & 3 \\
\hline Heavy Rainfall & 26 & 34 & 23 & 6 & 11 & 100 & 4 \\
\hline Temperature & 21 & 45 & 21 & 9 & 4 & 100 & 5 \\
\hline Extreme cold & 5 & 15 & 45 & 17 & 18 & 100 & 6 \\
\hline Densely fog & 4 & 31 & 41 & 19 & 5 & 100 & 7 \\
\hline Drought & 2 & 8 & 5 & 38 & 47 & 100 & 8 \\
\hline High tide & 1 & 14 & 20 & 22 & 43 & 100 & 9 \\
\hline
\end{tabular}




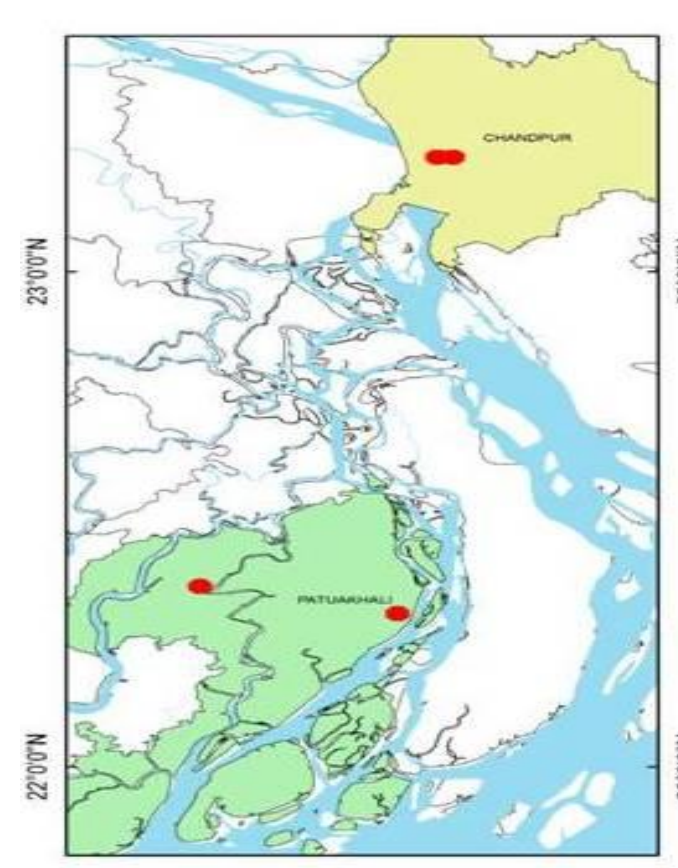

Area of Sample collection

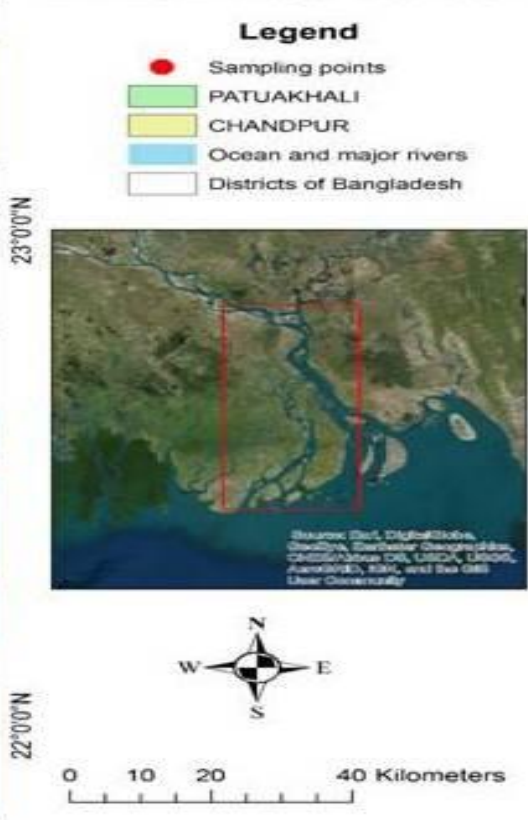

Figure 1. Map of the study area.

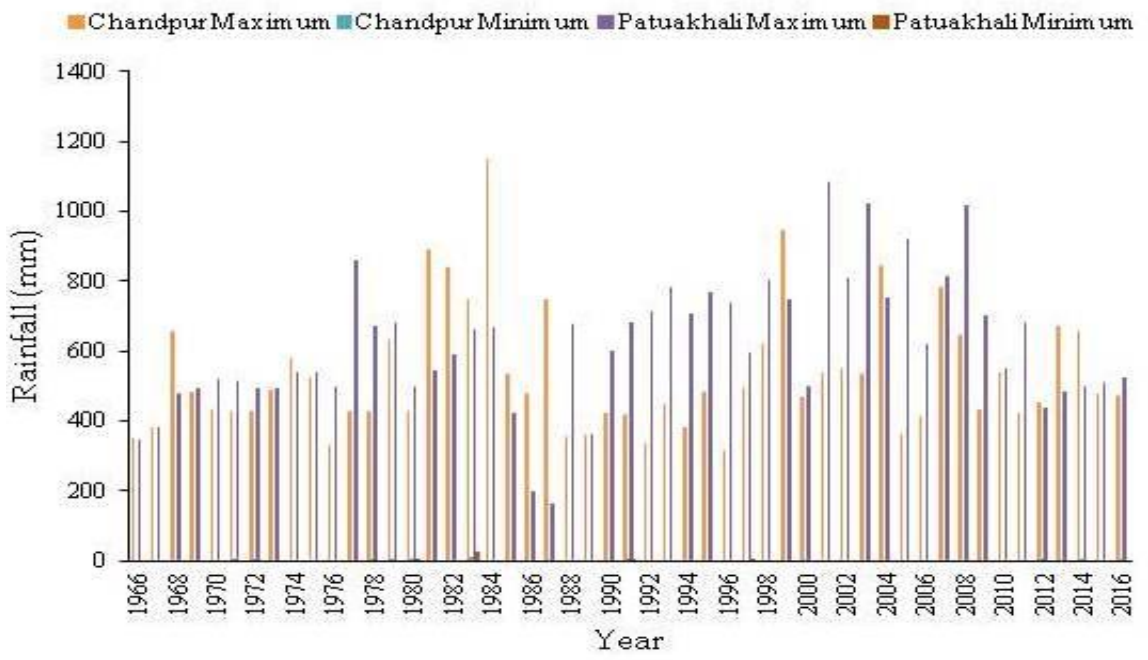

Figure 2. Annual maximum and minimum rainfall in the study area.

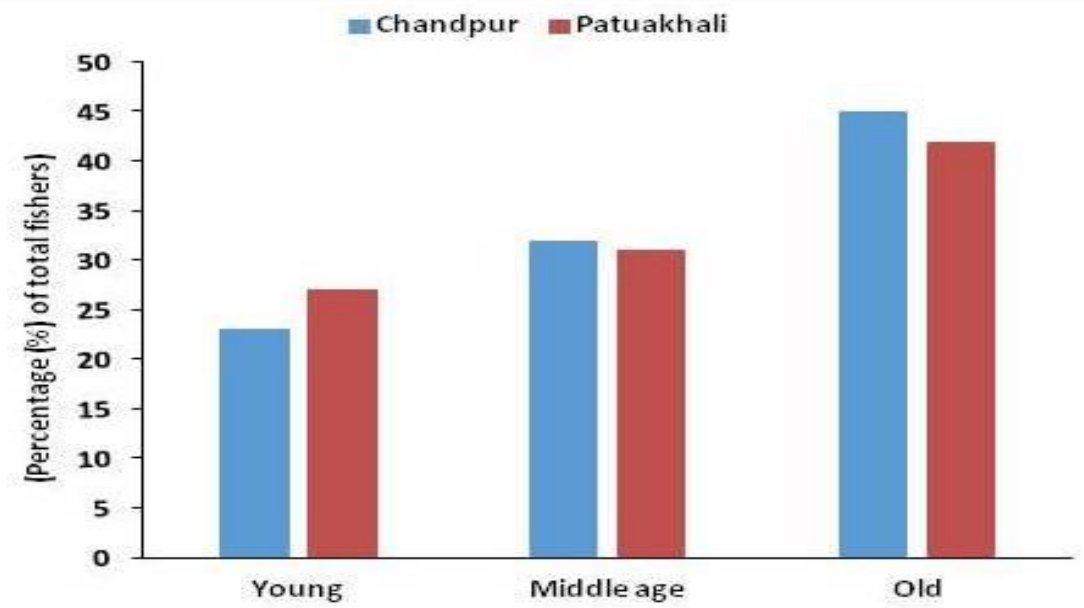

Figure 3. Age structure of fishers in the study area. 
ENuclear families $=$ Joint families

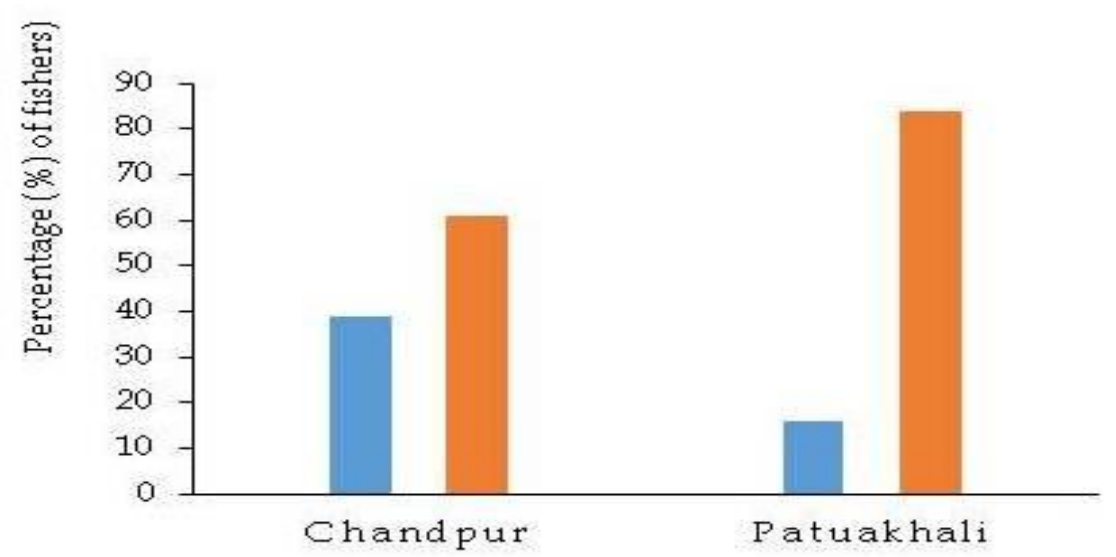

Figure 4. Family type of fishers in the study area.

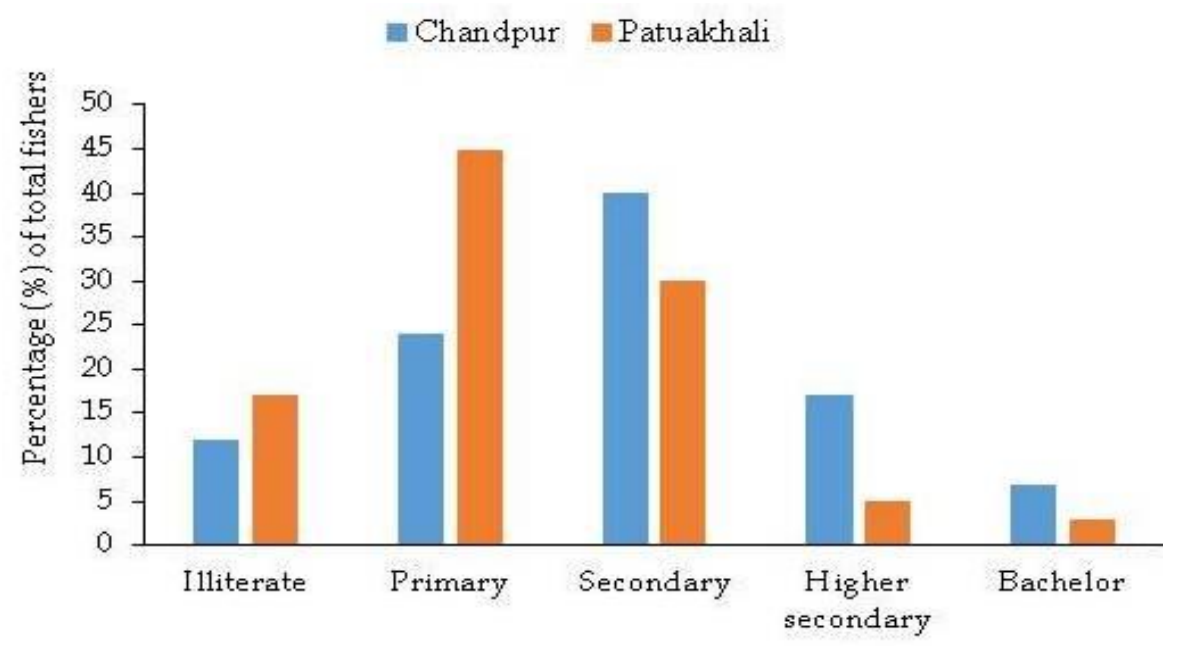

Figure 5. Educational level of fishers in the study area.

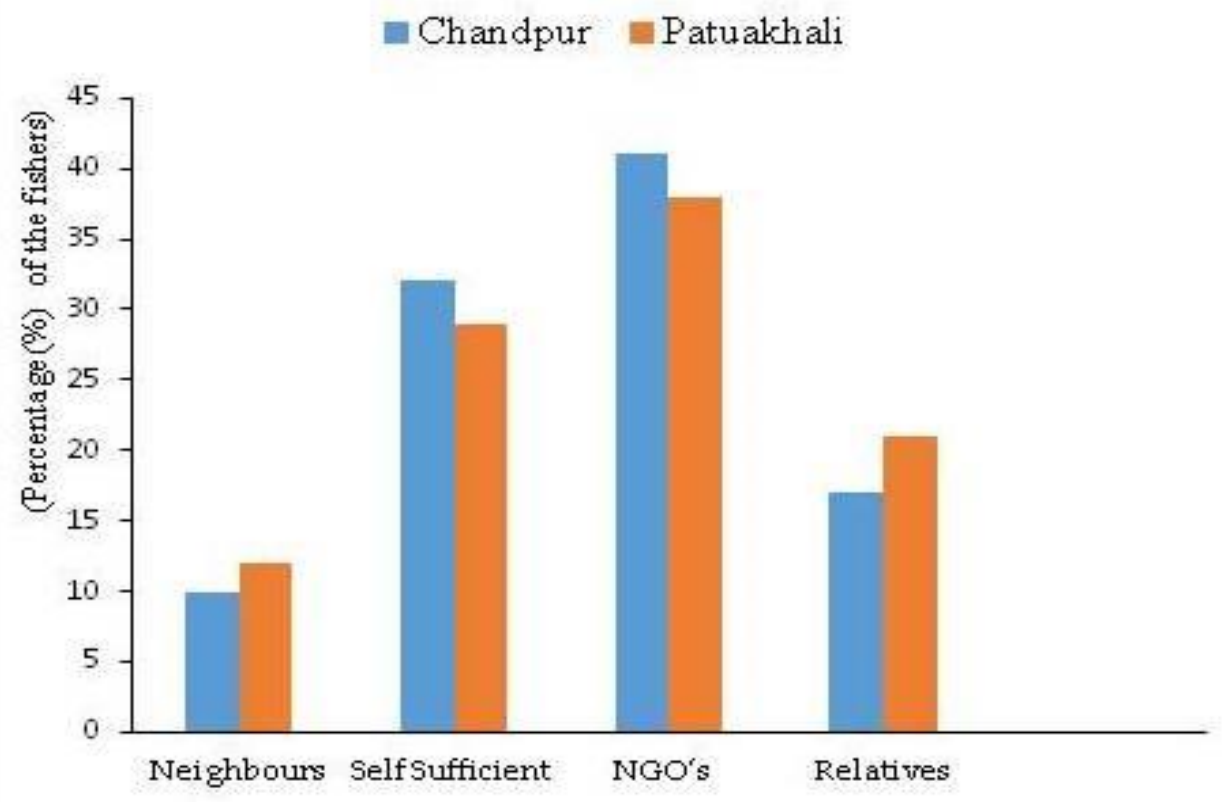

Figure 6. Credit access of the fishers in the study areas. 


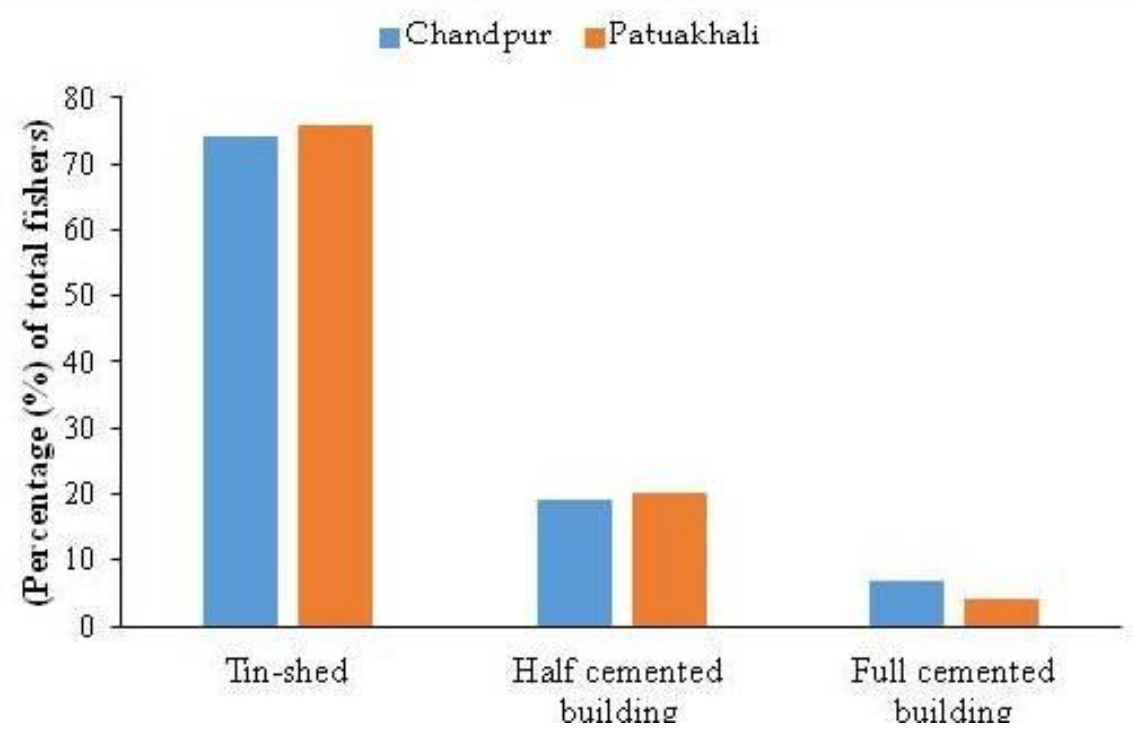

Figure 7. Housing condition of fishers in the study areas.

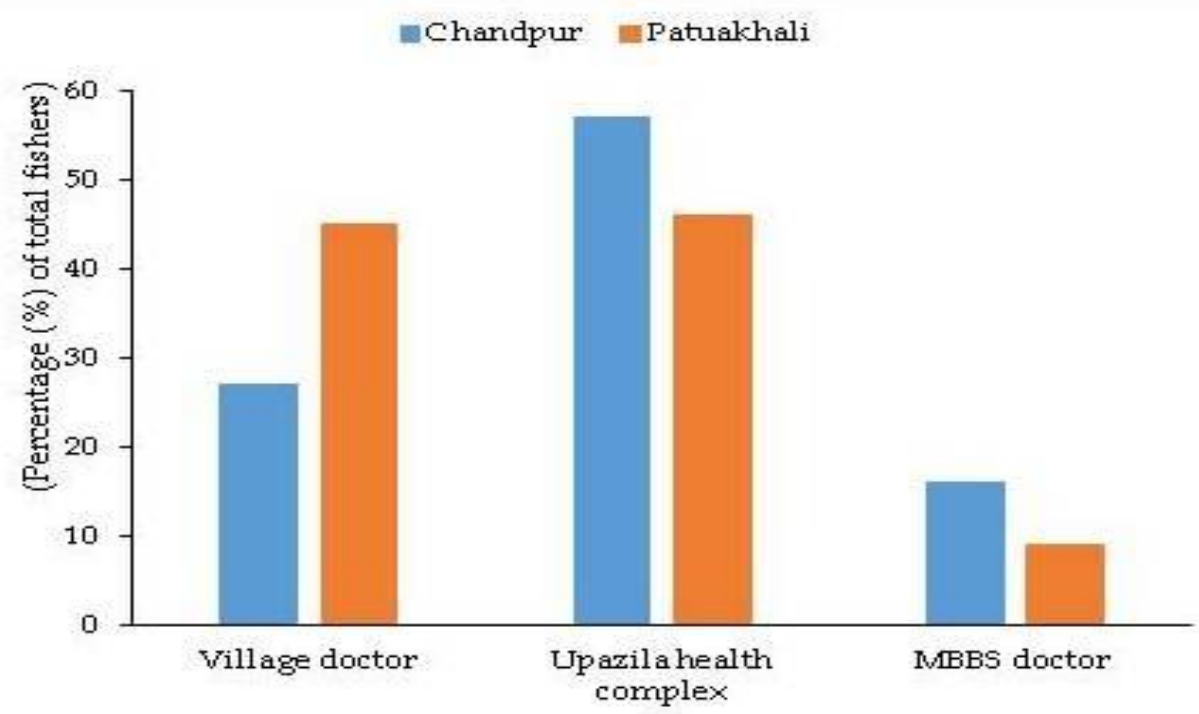

Figure 8. Health facilities of fishers' in the study area.

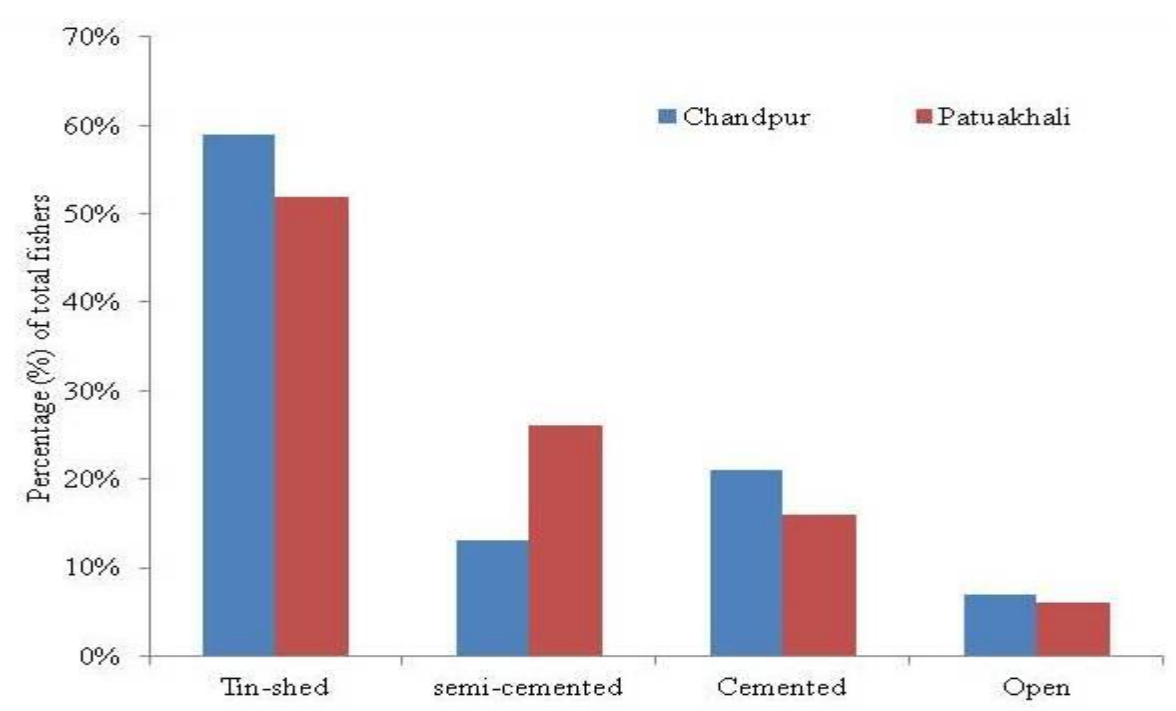

Figure 9. Sanitary facilities of fishers in the study area. 


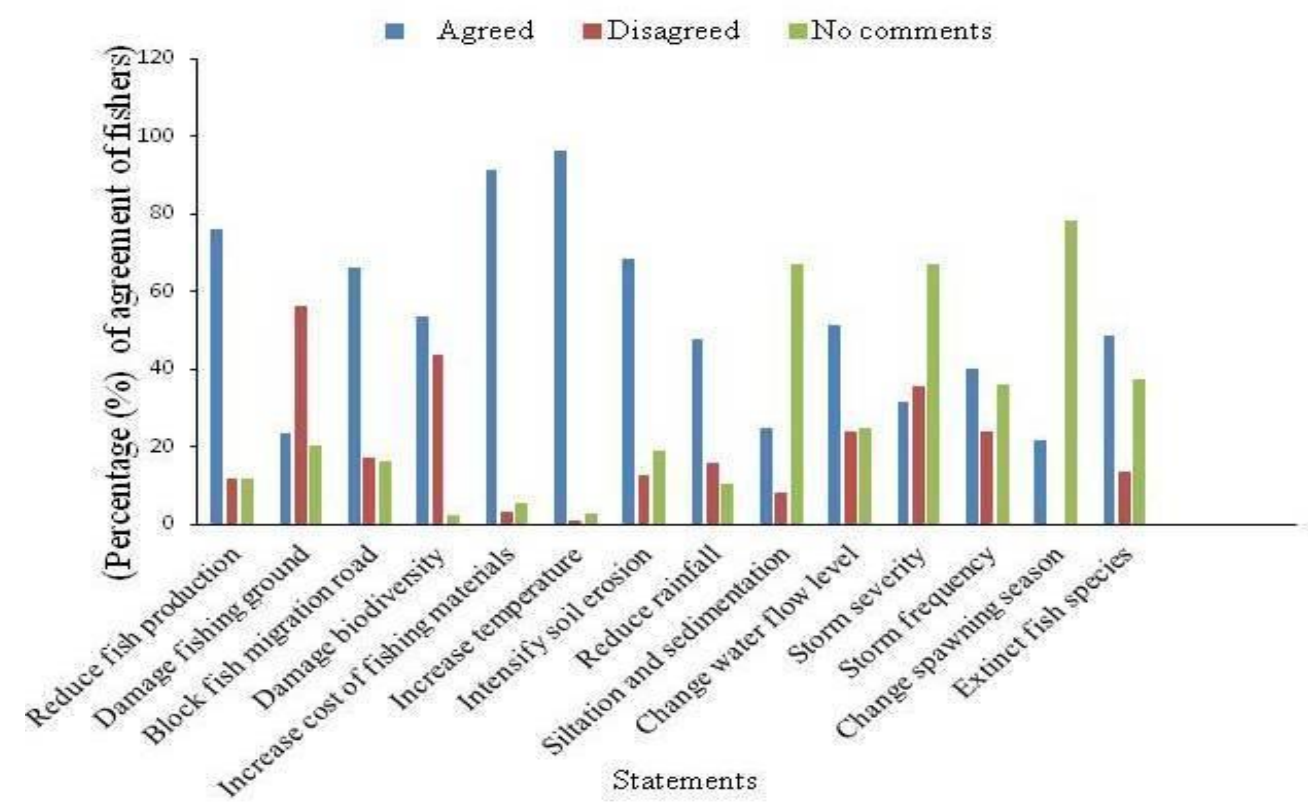

Figure 10. Agreement index regarding the impacts of climate change.

\section{Conclusions}

The present study mainly focuses on the livelihood status of the fishers in the Meghna, Laukhati and Galachipa river. The livelihood conditions of the fishers in the adjacent rivers area were not satisfactory. The fishers were deprived of many facilities. The education levels of the fishers were so poor. Lack of awareness as well as the poor income, the fishers has to take loan from Mohajan (moneyed person) at a high interest. Besides, due to change in climate and result of frequently occurring flood, storm surge and river bank erosion are largely affected. Consequently, many fishers shifted from their own land even they become destitute forever. From the above consideration it has been appeared that if no necessary steps are taken, this change will be epidemic in future. So, it is necessary to conduct awareness training programme on improve management of environmental risk and adaptive capacity.

\section{Acknowledgement}

Authors acknowledge to the Project Implementation Unit, National Agricultural Technology Program-Phase II Project (NATP-2), Bangladesh Agricultural Research Council (BARC), Farmgate, Dhaka-1215, Bangladesh for funding the project (no. CRG-718).

\section{Conflict of interest}

None to declare.

\section{References}

ADB (Asian Development Bank), 2005. Summery environmental impact assessment: South West area integrated water resources planning and management project in Bangladesh. Asian Development Bank.

Agrawala S, T Ota, AU Ahmed, J Smith and M Van Aalst, 2003. Development and climate change in Bangladesh focus on coastal flooding and the Sundarbans. Paris OECD, pp. 12-49.

Ahmed M, 2008. Status of common resource and future management in Chenchury beel to support increased access and livelihoods of poor people and to maintain sustainable environment. TARA Technical Assistance for Rural Advancement, Ulashi Sreejony Sangha (USS) and action aid Bangladesh.

Ahmed N and MAR Hossain, 1999. A study on socio-economic aspects of coastal fishermen of Bangladesh. Progress. Agric., 10: 151-155.

Ali H, MAK Azad, A Mohammed, MR Mohammad, MH Chowdhury and IS Mohammad, 2009. Livelihood status of the fishers in some selected areas of Tarakanda Upazila of Mymensingh district. J. Agrofor. Environ., 3: 85-89. 
Ali MH, M Hossain, ANGM Hasan and MA Bashar, 2008. Assessment of the Livelihood Status of the Fisherman in Some Selected Areas of Bagmara Upazila under Rajshahi District. J. Bangladesh Agril. Univ., 6: 367-374.

Ali MM, SU Mohammad, TMG Hossain and MA Hye, 1994. Rainfall features and effects of extreme events on statistical parameters of rainfall at Mymensingh. Bangladesh J. Agril. Res., 21: 157-165.

Allison H, AL Edward, MB Perry, WN Adger, B Katrina, CAS Declan, GMP Halls, DR John, LA Neil and KD Nicholas, 2009. Vulnerability of national economies to the impacts of climate change on fisheries. Fish Fish., 10: 173-196.

Baki MA, MR Islam, MM Hossain and NA Bhouiyan, 2015. Livelihood status and assessment of fishing community in adjacent areas of Turag-Burigonga river, Dhaka, Bangladesh. Int. J. Pure Appl. Zool., 3: 347353.

Coe TM and FA Jonathan, 2001. Human and natural impacts on the water resources of the Lake Chad basin. J. Geophys. Res., 106: 3349-3356.

Das MR, S Ray, U Kumar, S Begum and SR Tarafdar, 2015. Livelihood assessment of the fishermen community in the south west region of Bangladesh. J. Exp. Biol. Agri. Sci., 3:353-361.

DFID, 1999. Sustainable livelihoods guidance sheets. London: Department for International Development, UK. https://www.scribd.com/document/154608224

Ficke DA, CA Myrick and LJ Hansen, 2007. Potential impacts of global climate change on freshwater fisheries. Rev. Fish. Biol. Fisher., 17: 581-613.

Haedrich R, 1983. Estuarine fishes: In Ketchum BH (ed) Estuaries and enclosed seas. Elsevier, Amsterdam, pp. 183-208.

Hasan J and SM Mahmud, 2002. Study on the coastal fishing community of the Kalaiapara village: facts and observations. A project thesis in Fisheries and Marine Resources Technology Discipline, Khulna University, Khulna.

Honggang Z, B Cui, Z Zhang and X Fan, 2012. Species diversity and distribution for zooplankton in the intertidal wetlands of the Pearl River estuary, China. Procedia Environ. Sci., 13: 2383-2393.

Hossain MJ, MJ Sarker, MN Uddin, A Islam, IJ Tumpa and Z Hossain, 2018. Macrobenthos Presence in the Estuarine Waters of the Meghna River, Ramghati, Laksmipur, Bangladesh. World Appl. Sci. J., 36: 598-604.

Kabir KMR, RK Adhikary, MB Hossain and MH Minar, 2012. Livelihood status of fishers of the old Brahmaputra River, Bangladesh. World Appl. Sci. J., 16: 869-873.

Kamal AHM and MAA Khan, 2009. Coastal and estuarine resources of Bangladesh: management and conservation issues. Maejo Int. J. Sci. Technol., 3: 313-342.

Mahmud S, ML Ali and MM Ali, 2015. Present scenario on livelihood status of the fishers in the paira river, southern Bangladesh: constraints and recommendation. Int. J. Fish. Aquat. Stud., 2: 23-30.

Moni AH and MS Hossain, 2010. Response of environmental changes (Climate) in wetlands. In Proceedings 3rd International Conference on Bangladesh Environment.

Mullon C, P Fréon and P Cury, 2005. The dynamics of collapse in world fisheries. Fish Fish., 6:111-120.

O'Briena K, R Leichenkob, U Kelkarc, H Venemad, G Aandahla, H Tompkinsa, A Javedc, S Bhadwalc, S Bargd, L Nygaarda and J West, 2004. Mapping vulnerability to multiple stressors: climate change and globalization in India. Global Environ. Change, 14: 303-313.

Paul B, H Faruque and DA Ahsan, 2013. Livelihood Status of the Fisherman of the Turag River, Bangladesh. Middle East J. Sci. Res., 18: 578-583.

Pravakar P, BS Sarker, M Rahman and MB Hossain, 2013. Present status of fish farming and livelihood of fisherman in Shahrasti Upazila of Chandpur District, Bangladesh. Am- Eurasian J. Agric. Environ. Sci., 13: 391-397.

Quddus MA, MS Rahman and M Moniruzzaman, 2000. Socio-economic conditions of the pond owners of Demra, Dhaka. Bangladesh J. Fish. Res., 4: 203-207.

Rahaman MJ, NS Ema, MS Hossain, MM Rahman and Z Hossain, 2019. Effects of climate change on fisheries biodiversity of the Meghna, Laukhati and Galachipa river in Bangladesh. Eurasia J. Biosci., 13: 1-12.

Rahman A, 2009. Salt is killing us: Salinity and livelihood in a Bangladesh village, M.Sc. Thesis (Unpublished), Department of Social Anthropology, Lund University, Sweden.

Sarma PK, 2010. Scenario of haor vulnerabilities and other obstacles for sustainable livelihood development in Nikli upazila. J. Bangladesh Agril. Univ., 8: 283-290.

Smith VS and HT James, 1993. Coastal metabolism and the oceanic organic carbon balance. Rev. Geophys., 31 : 75-89. 
Sufian MA, M Kunda, MJ Islam, AT Haque and D Pandit, 2017. Socioeconomic Conditions of Fishermen of Dekar Haor in Sunamganj. J. Sylhet Agril. Univ., 4: 101-109.

Talukder MSU, SMA Ali, MM Haque and MA Hossain, 1988. A study on rainfall pattern of Bangladesh. Bangladesh J. Agri., 5: 59-64.

Zaman T, MAS Jeweland and AS Bhuiyan, 2006. Present status of livelihood of the fisherman of Mohanpur Upazila in Rajshahi District. Univ. J. Zool., Rajshahi Univ., 25: 31-35. 